\title{
Beet production efficiency and ways to increase it in case of negative market conditions in the commodity market
}

\author{
Ilgizar Gainutdinov ${ }^{1,2, *}$, Liliya Mikhailova ${ }^{1}$, Fayaz Avkhadiev $^{1}$, and Nail Asadullin ${ }^{1}$ \\ ${ }^{1}$ Kazan State Agrarian University, Kazan 420015, Russia \\ ${ }^{2}$ Tatar Institute of Retraining of Agribusiness Staff, Kazan 420064, Russia
}

\begin{abstract}
The relevance of the topic of the article is related to the need to develop agricultural markets at the regional level in order to increase the export potential of agricultural products. The purpose of the article is to find out the reasons for the decrease in the market price for sugar beet processed products, in particular white sugar, as well as to develop recommendations for optimizing the production and sale of sugar beet. The novelty of the study is to identify trends in the development of the market for raw materials for sugar production from sugar beets at the regional level and justification of the necessary priority measures to increase economic efficiency in the beet industry. The article presents the results of an analysis of the level of development of the commodity market for sugar producers. Priority directions for increasing production volumes and increasing the efficiency of sugar beet production as the main raw material for the production of white sugar and granulated sugar have been identified; recommendations have been given on ensuring sustainable growth in income from the sale of sugar beet root crops. The practical significance of the research results lies in the possibility of their use in the development of programs for the development of regional food markets, organizational, economic, technological measures to improve the efficiency of beet production in individual municipal areas to achieve high target indicators.
\end{abstract}

\section{Introduction}

The main areas of sugar beet cultivation in the Russian Federation are concentrated in the Krasnodar Krai, Voronezh, Lipetsk, Tambov and Kursk Regions. In 2019, more than 680 thousand hectares of sugar beet were concentrated in these regions. According to the Federal State Statistics Service, in all categories of farms, the sugar beet cultivation area amounted to 1144.9 thousand ha, which exceeded the level of 2018 by $1.6 \%$ (Table 1 ). The cultivated area of sugar beets in 2019 compared to the level of 2011 increased by $48.2 \%$ (by 372.4 thousand ha). Gross sugar beet harvest in Russia has grown significantly more than the sown area, due to the growth of root crops, the growth was, respectively, 39.4 and $23.7 \%$ [1]. According to experts, given this trend, as well as the growing productivity of the sugar beet industry, it will be possible to provide Russia with sugar with ever smaller crops of sugar beets every year. According to estimates, in order to meet domestic needs in the coming years, it will be enough to cultivate sugar beets on an area of 1-1.05 million ha.

In 2019, the Central Federal District with a share of about $55.4 \%$ became the main producer of white sugar. According to Sugar.Ru monitoring, the production volumes of raw materials and products of its processing are increasing every year. In 2019, Russia produced $7,278,636.9$ tons of white beet sugar, which is $16.0 \%$ more than the previous year's production [2].

Table 1. Sown area, gross yield and yield of sugar beet root crops by categories of farms in the Russian Federation and the Republic of Tatarstan *

\begin{tabular}{|c|c|c|c|c|c|c|}
\hline \multirow[t]{2}{*}{ Indicators } & \multicolumn{5}{|c|}{ Years } & \multirow{2}{*}{$\begin{array}{c}2019 \text { to } 2015 \\
{[\%]}\end{array}$} \\
\hline & 2015 & 2016 & 2017 & 2018 & 2019 & \\
\hline \multicolumn{7}{|c|}{ Russian Federation } \\
\hline Sown area [thousand ha] & 1021 & 1107 & 1198 & 1127 & 1145 & 112.1 \\
\hline Gross harvest [thousand tons] & 38989 & 51325 & 51913 & 42066 & 54350 & 139.4 \\
\hline Productivity [c/ha] & 388 & 470 & 442 & 381 & 480 & 123.7 \\
\hline $\begin{array}{l}\text { Production of white beet sugar } \\
\text { [thousand tons] }\end{array}$ & 5657.4 & 5951.39 & 6664.98 & 6272.71 & 7278.63 & 128.6 \\
\hline \multicolumn{7}{|c|}{ Republic of Tatarstan } \\
\hline Sown area [thousand ha] & 57,7 & 63.2 & 74.0 & 64.3 & 63.5 & 110.1 \\
\hline Gross harvest [thousand tons] & 2011.8 & 2327.3 & 3101.2 & 2109.1 & 2791.2 & 138.7 \\
\hline Productivity [c/ha] & 356 & 369 & 420 & 330 & 439.0 & 123.3 \\
\hline
\end{tabular}

* According to the Federal State Statistics Service and Tatarstanstat (updated on 03/27/2020)

* Corresponding author: ilgizar-gg@ mail.ru 


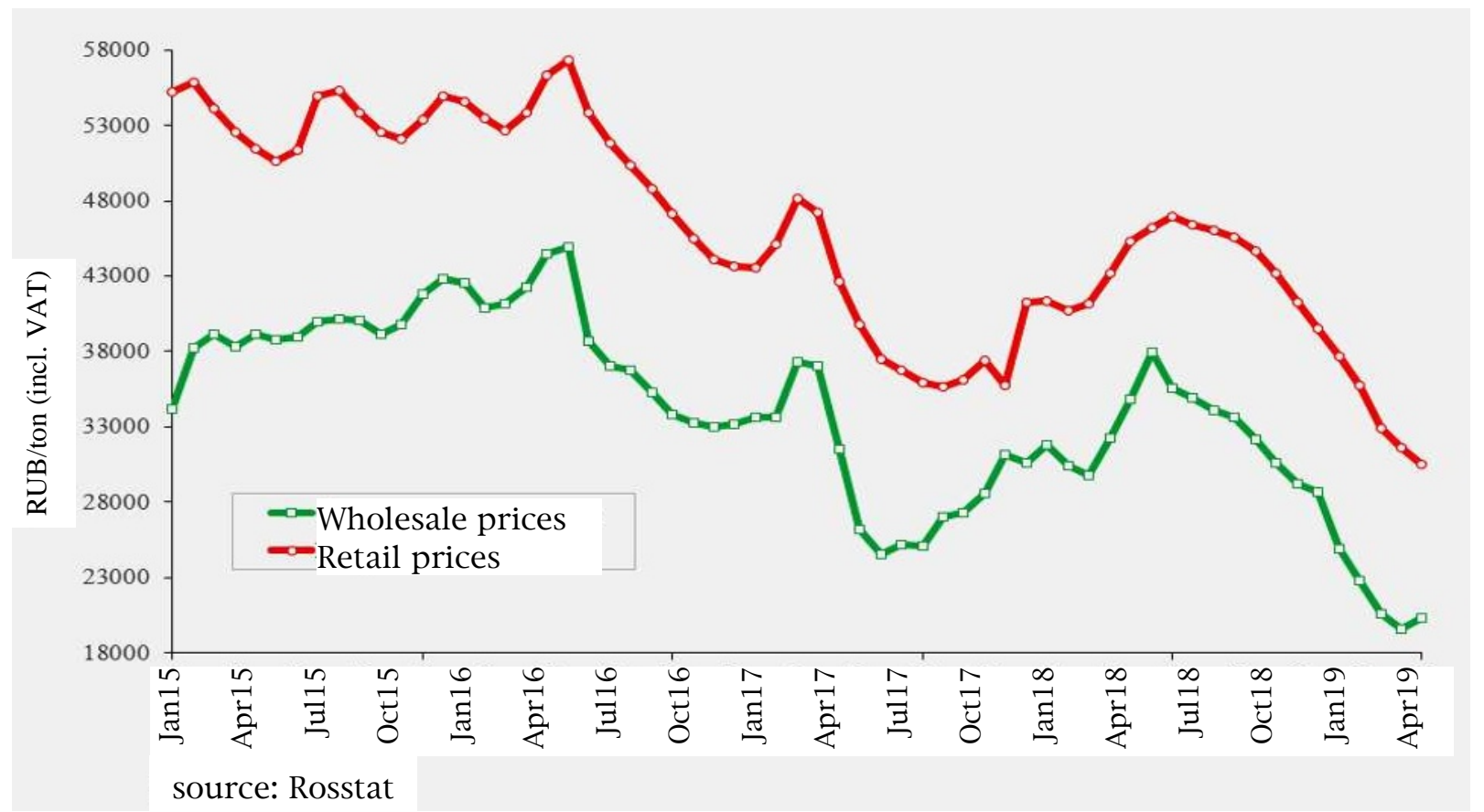

Fig. 1. Dynamics of prices for white sugar in 2015-2020 (source: Rosstat)

As can be seen from Figure 1, wholesale prices for white sugar in the domestic market of Russia for 2 years fell by 2 times. According to Rosstat, world prices for raw sugar on TheICE market are at the lowest level over the past 12 years. The prices for the contract for white sugar also fell significantly, the current quotation was $\$ 320 /$ t, which means that Russian sugar will be competitive when delivered by sea at a price of about 17.4 rubles $/ \mathrm{kg}$ excl. VAT (19.25 rubles $/ \mathrm{kg}$ incl. VAT) Most manufacturers of raw materials, and finished products have not yet realized the trend of the segment's development and continue to increase volumes, while expecting the previous profitability of production, but this should not be expected in the near future. Thus, the producers of raw sugar beet have the task of increasing the efficiency of the industry in the face of a negative trend in demand and selling prices for finished products.

\section{Materials and Methods}

The theoretical and methodological base of the study is the use of scientific principles and the concepts of economic theory. The theoretical and methodological basis was also made by the works of domestic agricultural economists on the topic under study, proceedings of international and all-Russian scientific and practical conferences devoted to the development of agriculture.

The general methodological basis of the study is system analysis. The diverse material necessitated the use of various approaches, methods and techniques for the scientific study of socio-economic processes, such as constructive, deterministic, retrospective, dynamic, and statistical, within the framework of system analysis.

In the course of the study, monographic, abstractlogical, computational-constructive, economic and statistical methods were used.
As the informational and factual basis of the study, we used official data of the Federal State Statistics Service of the Russian Federation, the Ministry of Agriculture of the Russian Federation, the Ministry of Agriculture and Food of the Republic of Tatarstan, the reporting documents of agricultural organizations, materials contained in official Internet sources, expert opinions, data obtained during author's analysis and calculations.

\section{Results}

The market conditions and the results of the introduction of scientific and technical research [3-6] have a significant influence on the efficiency of crop production sectors producing marketable products. The overproduction of sugar in the country has already resulted in a fall in sugar prices in 2019. By mid-July, wholesale prices fell to 26.6 rubles $/ \mathrm{kg}$ (Krasnodar, including VAT) against 32 rubles $/ \mathrm{kg}$ at the beginning of October 2018, when the season maximum was fixed $(2018 / 19)$. In the period 2017-2020, the average producer prices for sugar, white beet or cane and chemically pure sucrose in the solid state without flavoring or coloring additives fell by $35.9 \%$, from 28999.8 rubles/ton down to 18572.0 rubles/ton. The largest drop in average producer prices occurred in 2020 , then the growth rate was minus $29.3 \%$.

Over the past 3 years, growth in the production of secular sugar in Russia has exceeded 6 million tons. With volumes of own consumption of 5.5-5.8 million tons, the excess of production over consumption creates export potential. Correspondingly, the volume of supplies for export increased in comparison with 2011 by $3-4$ times. The inability to increase sugar export opportunities led to an increase in internal competition between sugar beet processors and a decrease in efficiency in the beet industry [7]. 
The current cost of sugar production in the country as a whole is in the range of $23-24$ rubles $/ \mathrm{kg}$, and a comfortable price for producers is 32 rubles $/ \mathrm{kg}$. The level of 26 rubles $/ \mathrm{kg}$ is lower than the acceptable profitability at which it is possible to ensure production and invest in the development of plants.

The production of white sugar planned by the Ministry of Agriculture of the Russian Federation about 7 million tons is possible, but this will not contribute to higher prices. At the end of 2019, they dropped to the level of 19 rubles $/ \mathrm{kg}$ in the Krasnodar Territory, the main producer of sugar beets.

The dynamics of growth of volumes of white sugar, growth of its stocks, as a result of a decrease in the selling price for it, all this reduces the efficiency of production of raw materials - sugar beet root crops. The cultivation of sugar beets in farms requires increasing costs for seeds, plant protection products, fertilizers, equipment operation, and a number of other material values.

Over 2011-2018, the cost of cultivating sugar beets in most beet-growing areas of the Republic of Tatarstan increased by an average of $2.1-19.3 \%$. At the same time, in a number of areas they were able to produce sugar beets while reducing costs per unit of production $[7,8]$. For example, in the Apastovsky district, the prime cost of sugar beet root crops decreased by $12.8 \%$, in the Kaybitsky and Nizhnekamsk regions by 35.5-35.1\%. In 2019, in 7 out of 12 municipal districts, the unit cost of production was lower compared to 2015 (Table 2).

The largest share in the costs of cultivating sugar beets is spent on fertilizers $(20 \%)$, agricultural production (15.6-16.8\%), seeds (11.7-12.6\%), and oil products $[9,10]$.

The economic situation of beet-growing farms depends on the level of selling prices on the raw materials market, and it had a negative conjuncture (Table 3). Thus, in most beet-growing areas, prices for root crops decreased by $5.1-52.3 \%$.

The sale price of one centner of sugar beet root crops by 2019 in all municipal areas had a downward trend, starting in 2016. The reason for the price reduction can be both market and domestic (the quality of root crops, contamination, the content of other impurities, etc.).
Table 2. The cost of sugar beets for sales, RUB/c

\begin{tabular}{|l|c|c|c|c|c|c|}
\hline \multirow{2}{*}{ Name of districts } & \multicolumn{5}{|c|}{ Years } & 2019 to \\
\cline { 2 - 7 } & 2015 & 2016 & 2017 & 2018 & 2019 & $\begin{array}{c}2015 \\
{[\%]}\end{array}$ \\
\hline Aksubaevsky & 155 & 157 & 164 & 297 & 149 & 96.1 \\
\hline Apastovsky & 170 & 159 & 129 & 193 & 148 & 87.1 \\
\hline Buinsky & 154 & 159 & 137 & 187 & 154 & 100.0 \\
\hline Drozhzhanovsky & 145 & 146 & 151 & 185 & 163 & 112.4 \\
\hline Zainsky & 122 & 138 & 140 & 133 & 119 & 97.5 \\
\hline Kaybitsky & 214 & 208 & 122 & 192 & 138 & 64.5 \\
\hline Leninogorsk & 188 & 192 & 159 & 135 & 192 & 102,1 \\
\hline Nizhnekamsk & 171 & 232 & 174 & 205 & 111 & 64.9 \\
\hline Nurlat & 174 & 179 & 194 & 173 & 193 & 110.9 \\
\hline Sarmanovsky & 155 & 181 & 128 & 150 & 113 & 72.9 \\
\hline Tetyushsky & 142 & 138 & 127 & 147 & 136 & 95.8 \\
\hline Tukaevsky & 109 & 112 & 160 & 157 & 130 & 119.3 \\
\hline
\end{tabular}

Table 3. Selling price of sugar beet root crops, RUB/c

\begin{tabular}{|c|c|c|c|c|c|c|}
\hline \multirow[t]{2}{*}{ Name of districts } & \multicolumn{5}{|c|}{ Years } & \multirow{2}{*}{$\begin{array}{c}2019 \text { to } \\
2015 \\
{[\%]}\end{array}$} \\
\hline & 2015 & 2016 & 2017 & 2018 & 2019 & \\
\hline Aksubaevsky & 235 & 217 & 194 & 204 & 195 & 83.0 \\
\hline Apastovsky & 227 & 241 & 120 & 200 & 146 & 64.3 \\
\hline Buinsky & 212 & 229 & 130 & 193 & 155 & 73.1 \\
\hline Drozhzhanovsky & 195 & 214 & 161 & 185 & 159 & 81.5 \\
\hline Zainsky & 259 & 201 & 177 & 163 & 127 & 49.0 \\
\hline Kaybitsky & 225 & 240 & 160 & 220 & 173 & 76.9 \\
\hline Leninogorsk & 196 & 195 & 160 & 163 & 186 & 94.9 \\
\hline Nizhnekamsk & 300 & 273 & 187 & 173 & 131 & 43.7 \\
\hline Nurlat & 249 & 238 & 213 & 182 & 194 & 77.9 \\
\hline Sarmanovsky & 235 & 229 & 167 & 172 & 132 & 56.2 \\
\hline Tetyushsky & 200 & 211 & 155 & 156 & 151 & 75.5 \\
\hline Tukaevsky & 241 & 244 & 182 & 165 & 146 & 60.6 \\
\hline
\end{tabular}

From Tables 4-5 it can be seen that the beet industry in 9 municipal districts was profitable, and in three municipal districts they received a loss. Profits in municipal areas began to decline also starting in 2016. Only producers of sugar beets in the Kaybitsky district were able to increase their profit over the past 5 years by $67.6 \%$, while the drought observed in some beetgrowing areas in 2018 caused a loss. In 2019, the volume of profit in the industry as a whole in the republic compared to 2015 decreased by 7 times.

Table 4. Profit from the sale of sugar beets, thousand rubles

\begin{tabular}{|c|c|c|c|c|c|c|}
\hline \multirow{2}{*}{ Name of districts } & \multicolumn{9}{|c|}{ Years 2019 to 2015 [ \%] } \\
\cline { 2 - 6 } & 2015 & 2016 & 2017 & 2018 & 2019 & \\
\hline Aksubaevsky & 73595 & 59941 & 33217 & -45280 & 59080 & 80.3 \\
\hline Apastovsky & 52220 & 100284 & -11292 & 4558 & -2608 & - \\
\hline Buinsky & 124818 & 168336 & -16578 & 7785 & 2510 & 2.0 \\
\hline Drozhzhanovsky & 26079 & 54350 & 10258 & 139 & -4147 & - \\
\hline Zainsky & 507712 & 256273 & 168672 & 115602 & 39508 & 7.8 \\
\hline Kaybitsky & 9385 & 27058 & 30266 & 26532 & 15725 & 167.6 \\
\hline Leninogorsk & 6749 & 2076 & 923 & 10975 & -1567 & - \\
\hline Nizhnekamsk & 148709 & 33391 & 10918 & -17949 & 8658 & 5.8 \\
\hline Nurlat & 153533 & 109586 & 40728 & 8144 & 2777 & 1.8 \\
\hline Sarmanovsky & 218860 & 148590 & 189623 & 80392 & 66075 & 30.2 \\
\hline Tetyushsky & 85356 & 144282 & 49120 & 10381 & 34900 & 40.9 \\
\hline Tukaevsky & 161012 & 138962 & 30614 & 10043 & 20661 & 12.8 \\
\hline Total in Republic of Tatarstan & 1567044 & 1307712 & 592392 & 254282 & 223641 & 14.3 \\
\hline
\end{tabular}

The main reason for the loss in some municipal areas is the increase in production costs and lower prices for root crops, which, in turn, is due to the high costs of cultivating sugar beets. So, starting from 2015, the 
profitability of the production and sale of sugar beets decreased from 55.0 to $7.1 \%$, i.e. by 48.4 percentage points. In Apastovsky, Drozhzhanovsky and Leninogorsk districts, sugar beet production in 2019 was unprofitable.

Let us consider what factors influenced the volume of revenue and profits from the production and sale of sugar beets among other types of marketable crop products in the Republic of Tatarstan (Tables 6-7).

Table 5. Profitability of the production and sale of sugar beets, $\%$

\begin{tabular}{|l|c|c|c|c|c|}
\hline \multirow{2}{*}{ Name of districts } & \multicolumn{5}{|c|}{ Years } \\
\cline { 2 - 6 } & 2015 & 2016 & 2017 & 2018 & 2019 \\
\hline Aksubaevsky & 51.6 & 38.6 & 18.8 & -31.2 & 31.2 \\
\hline Apastovsky & 33.7 & 51.7 & -7.0 & 3.7 & -1.5 \\
\hline Buinsky & 37.9 & 43.9 & -5.2 & 3.0 & 0.8 \\
\hline Drozhzhanovsky & 34.8 & 47.2 & 6.4 & 0.1 & -3.0 \\
\hline Zainsky & 112.0 & 45.2 & 26.6 & 22.5 & 6.9 \\
\hline Kaybitsky & 5.2 & 15.5 & 30.7 & 14.2 & 25.3 \\
\hline Leninogorsk & 4.5 & 1.2 & 0.8 & 20.4 & -3.0 \\
\hline Nizhnekamsk & 75.8 & 17.7 & 7.3 & -15.7 & 17.9 \\
\hline Nurlat & 43.4 & 32.7 & 10.2 & 5.2 & 0.6 \\
\hline Sarmanovsky & 51.3 & 26.3 & 30.7 & 14.7 & 17.1 \\
\hline Tetyushsky & 41.5 & 52.8 & 21.6 & 6.1 & 11.1 \\
\hline Tukaevsky & 120.2 & 117.4 & 13.8 & 5.5 & 12.3 \\
\hline $\begin{array}{l}\text { Total in Republic of } \\
\text { Tatarstan }\end{array}$ & 55.0 & 39.4 & 15.6 & 8.7 & 7.1 \\
\hline
\end{tabular}

Table 6. The influence of factors on the volume of revenue by main types of agricultural products for 2018 in the Republic of Tatarstan, million rubles.

\begin{tabular}{|l|c|c|c|}
\hline \multirow{2}{*}{ Products } & \multicolumn{3}{|c|}{ Deviation from level of 2017 } \\
\cline { 2 - 4 } & \multirow{2}{*}{ revenue } & \multicolumn{2}{|c|}{ due to } \\
\cline { 3 - 4 } & & sales volume & $\begin{array}{c}\text { selling } \\
\text { prices }\end{array}$ \\
\hline Grain & 2288.4 & -709.4 & 2997.8 \\
\hline Potatoes & 41.1 & -1.5 & 42.6 \\
\hline Sugar beet & -1138.8 & -1222.4 & 83.7 \\
\hline Rape & 748.9 & 636.1 & 112.8 \\
\hline
\end{tabular}

As you can see, compared with 2017, cash proceeds from the sale of sugar beets decreased by 1138.8 million rubles, primarily due to a decrease in sales volumes. The total profit also decreased by 333.2 million rubles. This was mainly due to an increase in the cost of production, i.e. growth in the costs of cultivating sugar beets and by reducing sales volumes. The impact of rising sugar beet prices did not have a significant effect on cash revenue and profit.

Thus, an increase in the production of sugar beets as the main raw material for the production of white sugar and granulated sugar led to an increase in the production of white sugar and an increase in its reserves in the country. White sugar production volumes of more than 7 million tons in 2019/2020 led to an excess of stocks, almost 1 million tons, which contributed to lowered prices for finished products from 28989.8 rubles/ton to 18572.0 rubles/ton.

All this also led to a decrease in the price of raw materials-sugar beet root crops-to $52.3 \%$, as well as a drop in profit volumes and a decrease in production profitability. In order to maintain the attractiveness of the industry for beet-growing farms, it is necessary to optimize the total cultivated area of sugar beet cultivation at the level of 900-1000.0 thousand ha in Russia, with an average yield of $480 \mathrm{~kg} / \mathrm{ha}$ achieved in 2019.

The Russian government and the executive bodies of the constituent entities of the Russian Federation need to look for opportunities to export white sugar together with large producers of white sugar in the country.

Table 7. Influence of factors on volume of profit for main types of agricultural products for 2018 in Republic of Tatarstan, million rubles.

\begin{tabular}{|l|c|c|c|c|c|c|}
\hline \multirow{2}{*}{ Products } & \multicolumn{2}{|c|}{$\begin{array}{c}\text { Profit from } \\
\text { sales }\end{array}$} & \multicolumn{4}{c|}{ Deviation } \\
\cline { 2 - 7 } & 2017 & 2018 & total & $\begin{array}{c}\text { sales } \\
\text { volume }\end{array}$ & base cost & price \\
\hline Grain & 1019.2 & 1949.1 & 930.1 & -56.7 & -2010.6 & 2997.8 \\
\hline Potatoes & 68.1 & 82.1 & 13.9 & -0.3 & -28.4 & 42.6 \\
\hline $\begin{array}{l}\text { Sugar } \\
\text { beet }\end{array}$ & 592.4 & 259.2 & -333.2 & -164.9 & -251.9 & 83.7 \\
\hline Rape & 154.6 & 225.7 & 71.1 & 110.7 & -152.4 & 112.8 \\
\hline $\begin{array}{l}\text { Total } \\
\text { crop } \\
\text { producti } \\
\text { on }\end{array}$ & 1834.3 & 2516.1 & 681.9 & -111.2 & -2443.3 & 3236.9 \\
\hline
\end{tabular}

To increase the efficiency of the beet industry is possible only by reducing the cost of means of production and maintaining the level of productivity at the level of $450-500 \mathrm{~kg} / \mathrm{ha}$, with high sugar content of root crops.

The task of ensuring industry efficiency is also relevant for many European countries. In order to prevent loss-making and preserve the industry, quotas of production volumes are practiced in these countries. Some countries (Ireland) as a whole completely reduce the cultivated area of sugar beets, while a number of others (Italy, Spain, Greece, the Czech Republic and Denmark) significantly reduce the cultivated areas of sugar beets.

In order to increase the efficiency of sugar beet production it is necessary to:

- complete the placement of sugar beets according to the best predecessors on soils with a neutral reaction;

- ensure the return of sugar beets in crop rotation only after 5 years;

- provide for the placement of crops after winter crops in clean fallows;

- ensure the introduction of complex mineral fertilizers in combination with micronutrient fertilizers and liming of soils;

- switch to resource-saving soil-saving technologies for sugar beet cultivation;

- provide highly effective plant protection products;

- timely and efficiently prepare equipment for cleaning.

\section{Conclusions}

To summarize, we can draw the following conclusions: 
1) Currently, the Russian beet-growing regions fully satisfy their own demand for raw materials, including the Republic of Tatarstan;

2) Maintaining the efficiency of the beet industry directly depends on increasing export volumes of finished products-white sugar and granulated sugar;

3) One of the main ways to reduce the costs of cultivating sugar beets is the development of selection and seed production of sugar beets and the complete self-sufficiency of seeds of new varieties and hybrids of domestic production;

4) Reducing the costs of processing sugar beets in sugar refineries depends on the modernization of production capacities and the extension of the processing time of raw materials while ensuring the sugar content of root crops;

5) In order to ensure a positive market situation for raw materials and finished products, export volumes of finished products should be increased by more than 1 million tons of finished products throughout Russia as a whole.

\section{References}

1. Rosstat, Official source, Retrieved from: https://www.gks.ru/enterprise_economy
2. Online source, Retrieved from: http://sugar.ru/node/31346

3. N.F. Kashapov, M.M. Nafikov, A.R. Nigmatzyanov, IOP Conf. Ser. Mater. Sci. and Eng., 012047 (2019)

4. L. Sitdikova, I. Gainutdinov, D. Fayzrakhmanov, F. Mukhametgaliev, Bull. of Kazan State Agrar. Univer., 10(3(37)), 46-51 (2015)

5. L. Mikhailova, O. Tselishchev, Urgent scientific and technical means and agricultural problems, in: Mater. of the III National Sci. and Pract. Conf. (Kemerovo, 30 December 2019), Retrieved from: http://ksai.ru/upload/files/sborniki.

6. L. Mikhailova, A. Nikolaev, Actual scientific and technical means and agricultural problems: Mater. of the III National Sci. and Pract. Conf. (Kemerovo, 30 December 2019)

7. I. Gainutdinov, M. Kondratieva, Vector of Econ., 5(5), 52-57 (2016)

8. F.N. Mukhametgaliev, L.F. Sitdikova, F.N. Avkhadiev., V.Ya. Petrova., BIO Web of Conf., 00082 (2020)

9. F. Avkhadiev, Bull. of Kazan State Agrar. Univer., 6(1(19)), 5-7 (2011)

10. N. Asadullin, M. Khismatullin, L. Asadullin, Bull. of Kazan State Agrar. Univer., 6(3(21)), 17-19 (2011) 